\title{
The Effects of Students' Perception on Teacher's Pedagogic Competence and Language Attitude Towards Student's English Achievement
}

\author{
(Survey at State Vocational High Schools in Serang Banten)
}

\author{
Hayati Nupus ${ }^{1}$
}

${ }^{1}$ Department of English Education Graduate School, Universitas Indraprasta PGRI Jakarta

\begin{tabular}{l} 
ARTICLE INFO \\
\hline Keywords: \\
Students' Perception \\
Teacher's Pedagogic \\
Competence \\
Language' Attitude \\
English' Achievement
\end{tabular}

ARTICLE INFO

\begin{abstract}
This research is a kind of survey and aims to find and analyze empirically the efects of students' perception on Teacher's pedagogic competence towards student's English achievement, the effects of language attitude towards Student's English achievement, and the effects of The student perception on teacher's pedagogic competence and language attitude towards student's English achievement. The Method used in this research is a survey method. The observed population of this research is student of second grade of state vocational high schools in Serang-Banten, sample was taken as many as 50 students, the sample was gained through simple random sampling, which means that the reseacher mixed the subjects in the population so that they will be considerably the same. The collecting of the data used by the questioner and collecting of student's English achievement. The gained data was analyzed by using correlation technique and multiple regressions. Previously, the prerequisite test before examining the regression test must be accomplished, such as normality test and linearity test. This research is done on October 2017. The result of the research concluded: 1).There are any significant effects of student perception on Teacher's pedagogic competence and Language Attitude collaboratively towards students' English Achievement students at State Vocational High Schools in Serang-Banten. It can be proved by Sig $=0,000<0.05$ and Fo $=47,843,2)$.There is a significant effect of student perception on Teacher's pedagogic competence towards students' English Achievement students at State Vocational High Schools in Serang-Banten. It can be proved by Sig $=0,010<0.05$ and th $=2,677,3)$. There is a significant effect of the Language Attitude towards students' English Achievement students at State Vocational High Schools in Serang-Banten. It can be proved by Sig $=0.000<0.05$ and th $=4,137$.
\end{abstract} medium, provided the original work is properly cited. (๖ 2019 Hayati Nupus

\section{INTRODUCTION}

Language cannot be separated from human's life. It is one of the universal systems in a culture that functions as a means of communication. It enables people to interact, communicate, and make

${ }^{1}$ Corresponding author's address: Department of English Education Graduate School, Universitas Indraprasta PGRI Jakarta

e-mail: hnupus32@yahoo.com 
sense of the world so that it is dynamic, and it develops and changes over time as a result of many differentinfluences. In addition, it is used by human beings in communicating with each other, both in oral and in written discourse. English is one of languages, which are used by people all around the world to communicate with each other. Teaching English to students should cover the four language skills including speaking, reading, writing, and listening. While the language components that should also be taught are pronunciation, vocabulary, and grammar of English. English is a foreign language in our country which is taught from Elementary school to university. English is very important to adopt and to develop science, technology and culture. By mastering English, it is hoped that the students can develop themselves to be intellectual, skillful, and having Indonesian personality in such a way that they can participate in the national development. Teaching English to students should cover the four language skills including speaking, reading, writing, and listening. While the language components that should also be taught are pronunciation, vocabulary, and grammar of English.

The fact in the fields shows that the vocational students are still a few who are able to speak English well, it is influenced by several factors such as student perceptions of teacher pedagogic competence, and language attitude of students themselves that can ultimately affect student achievement results. Student achievement is the result of learning that can be achieved by the students at the time of assessment. Assessment is the process of collecting and processing information to measure the achievement of student learning outcomes. Teachers can provide an assessment of the success of the process as measured by a certain size. The results of this assessment reflect student achievement.

To measure and evaluate the success rate of learning can be done with the test of learning achievement. Among them with formative tests, submatif, sumatif. In relation to this research, the learning achievement is seen from the value of the final anniversary of Gas Semester obtained by the students. Problems that arise is the achievement of learning that has not reached the optimal point becomes a problem that many teachers meet in achieving the success of teaching and learning process. Problems of student achievement arise because many factors both derived from within students and factors that come from outside the student self. Learning achievement in the context of teaching and learning process in school, often associated with achievement or academic performance. And determination of the minimum boundary of student achievement. According to DJaali (2002: 37), "achievement is the academic performance of a student's learning achievement, which can be known through the test of learning achievement". Achievement is an assessment of the success rate of students achieving the goals set in a program (Shah: 2010: 139). The equivalent of the word achievement is defined as the assessment process to describe the achievement of a student in accordance with the predefined criteria.In addition to the word achievement and assessment there are also other words that are relatively more ordinary we hear in the world of education that is test, exam, and repetition.

In teaching and learning activities in the school environment, a teacher interacts with students, so that with the interaction can lead to self-perception in students against teachers who teach. According to (Irwanto :1996) perception which means visions, responses, understand or respond to something. While the experts definitively express many opinions that each is different from each other. (Alisuf sabri 1995: 45) argues that "perception is a process whereby an individual can recognize objective objects and facts by means of the sense device". Then (A. Fauzi 1999: 37) suggests that "perception is interpreting the existing stimulus in the brain. While (Sarlito Wirawan Sarwono 1996: 39), argues that "Perception is the ability to discriminate, group, focus objects that are close. Meanwhile, according to (Slameto 2003: 97) argues that "Perception is a process that involves the entry of messages or information into the human brain that continuously make contact with the environment. This connection is done through vision, hearing touch, taste, and smell. 
In the process of interaction of teaching and learning teachers are people who provide lessons and students are people who receive lessons. In transferring knowledge to students required knowledge or skills or skill as a teacher. Without this all is not possible the process of learning and teaching interaction can run conducive. This is where competence in the sense of absolute ability required teachers in performing their duties as educators. Competence is an absolute ability of teachers to have the lever as an educator can be done well. Moving from this understanding of competence is something that cannot be separated from educational activities and teaching. Competence comes from the English language "Competence" which means skill, ability. The competence of teachers means the possession of teacher knowledge, and the possession of skills and abilities as teachers in performing their duties. Besides according to Prof. Dr. J. Hoogveld (Dutch) pedagogic is a science that studies the problem of guiding children ka certain destination direction, that is so he will be "able to independently complete the task of life". So Pedagogic is the Science of Educating Children.

To be a teacher who has the competence or ability then required to develop three aspects of ability, namely personal, professional, and community. Kunandar (2007: 56) Pedagogic competence or ability is basically the ability of teachers in managing student learning. Pedagogic ability to be one type of ability that must be mastered by the teacher. Pedagogic ability is a distinctive competency that will differentiate teachers from other professions. Mastery of pedagogic skills along with professionals will determine the level of process success and student learning outcomes. Pedagogic competence or ability is obtained through continuous and systematic learning, both in pre-service (teacher candidate education) and during the position supported by talents, interests and other teacher potential of each individual concerned.

Attitudes play an important role in a person's desire and willingness to learn English. Attitude which is defined as a psychological tendency that is expressed by evaluating a particular entity with some degree of favor or disfavor (Albaracin, 2005: 4) has a great influence on the process of learning English. The learner's attitude can effect the way they see everything around them. When they have positive attitude, this will have an influence on the learning process (Leaver, et al., 2005: 93).

\section{Analysis of the Research Result and Discussion}

This section presented the analyzing and discussion of the data processing result about Students' English achievement (Y), Student Perception on Teacher's Pedagogic competence (X1), and Language Attitude (X2). The result of the research and discussion that consist of data, requirements test of regression analysis, hypothesis test, and discussion of research findings. In analyzing the data was puposed on the hypothesis test and through three variables in the form of frequency distribution, the size of the central symptoms, histogram of variable polygon, and requirement test of regression analysis. To describe the effect of the variable is used by simple regression and multiple regression. The assumption test research used by Normality test through Kolmogorov-Smirnov test.

\section{Data Description}

The Method used in this research is a survey method. The observed population of this research is student of second grade of state vocational high schools in Serang-Banten, sample was taken as many as 50 students, the sample was gained through simple random sampling, which means that the reseacher mixed the subjects in the population so that they will be considerably the same. The collecting of the data used by the questioner and collecting of student's English achievement. The gained data was analyzed by using correlation technique and multiple regressions. Previously, the prerequisite test before examining the regression test must be accomplished, such as normality test and linearity test.

The research result description is served by the variability of these three variables that involve maximum score, minimum score, deviation score, minimum score, deviation standard, modus, 
median, and data distrubution as the basic of the discussion next. All of the data description as follows:

Table 1. Description data

\begin{tabular}{|c|c|c|c|c|}
\hline \multicolumn{5}{|c|}{ Statistics } \\
\hline & & $\begin{array}{l}\text { Student } \\
\text { Perception On } \\
\text { Teacher's } \\
\text { Pedagoic } \\
\text { Competence } \\
(\times 1)\end{array}$ & $\begin{array}{l}\text { Language } \\
\text { Attitudes (X2) }\end{array}$ & $\begin{array}{c}\text { Student's } \\
\text { English } \\
\text { Achievement } \\
\end{array}$ \\
\hline \multirow[t]{2}{*}{$\bar{N}$} & Valid & 50 & 50 & 50 \\
\hline & Missing & 0 & 0 & 0 \\
\hline \multicolumn{2}{|c|}{ Mean } & 113.20 & 104.72 & 74.06 \\
\hline \multicolumn{2}{|c|}{ Median } & 113.00 & 105.00 & 73.00 \\
\hline \multicolumn{2}{|c|}{ Mode } & 115 & 106 & $67=$ \\
\hline \multicolumn{2}{|c|}{ Std. Deviation } & 8.552 & 10.960 & 8.047 \\
\hline \multicolumn{2}{|c|}{ Variance } & 73.143 & 120.124 & 64.751 \\
\hline \multicolumn{2}{|c|}{ Minimum } & 87 & 78 & 57 \\
\hline \multicolumn{2}{|c|}{ Maximum } & 131 & 128 & 90 \\
\hline \multicolumn{2}{|c|}{ Sum } & 5660 & 5236 & 3703 \\
\hline
\end{tabular}

a. Multiple modes exist. The smallest value is shown

\section{Description of Student's English Achievement}

In collecting the data of student's English achievement the research used multiple choice as many as 30 items. The data of Student's English achievement has been obtained from the test score of 50 students as the research sample or respondent. The scores obtained are 57 as the lowest, 90 as the highest, 74,06 as the mean (rata-rata), 73 as the median, another 67 as the modus, and 8,047 as the $S$ (simpangan baku).

From the data analysis result for students' English achievement variable, it can be said that Student's English achievement of State Vocational High schools 1 and 3 Serang-Banten in relatively good. This fact is indicated by the average score achievement of 74,06 (the mean). It means that mean of the score of students' English achievement of State Vocational High schools 1 and 3 Serang-Banten in relatively good. Histogram of variable polygon of students' English achievement as follows:

Student's English Achievement $(Y)$

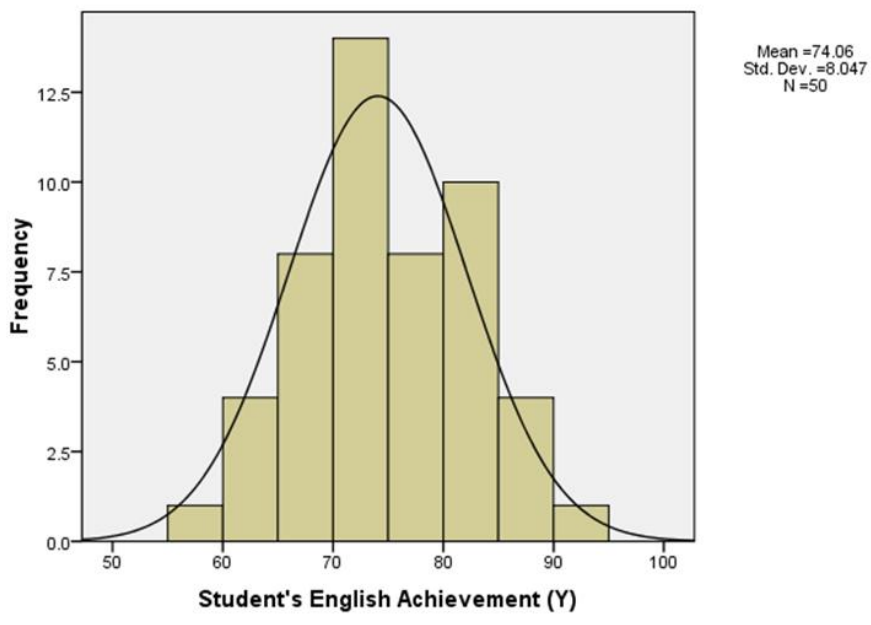

\section{Description of Student Perception on Teacher's Pedagogic Competence}

Student perception on teacher's pedagogic competence is the score of the students respond to the questionnaire that has been constructed based on the indicators of know the characteristics of students, master learning theories and principles of learning, able to develop the curriculum, create educational learning activities, develop student potential, and others. 
Based on the data research for the Student Perception on Teacher's Pedagogic Competence that collected by using the research instrument of measure the Student Perception on Teacher's Pedagogic Competence uses 30 Question items that proposed for the respondents. The data of Student Perception on Teacher's Pedagogic Competence has been obtained from the questionnaire score which was answered by 50 students, with the lowest : 87 , the highest : 131 , the mean : 113,20, the median : 113,00, the modus : 115, and the $S: 8,552$. From the histogram and the frequency polygon, it can be inferred that Student Perception on Teacher's Pedagogic Competence of State Vocational High Schools 1 and 3 Serang - Banten has a normal distribution. Histogram of variable polygon of Student perception on Teacher's Pedagogic as follows:

Student Perception On Teacher's Pedagoic Competence (X1)

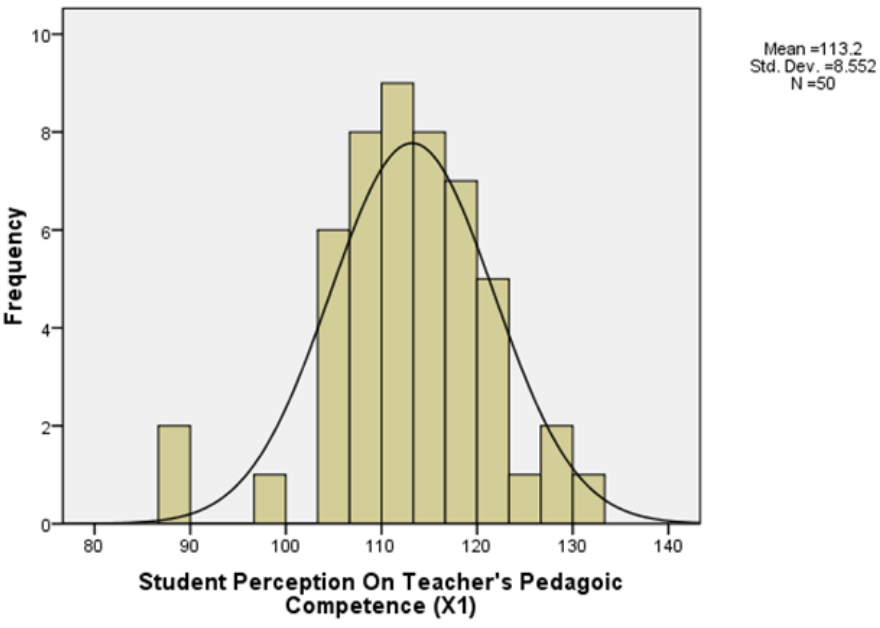

\section{Description of Language attitude}

The data of Language Attitude has been obtained from the questionnaire score which was answered by 50 students are the respondents, with the lowest score : 78, the highest : 128 , the mean : 104,72, the median : 105,00, the modus : 106 , and the $S: 10,960$.

From the calculation, it can be inferred that student's Language Attitude of State Vocational High Schools 1 and 3 Serang - Banten is relatively good. It is indicated by the average score achievement or the mean of Language Attitude : 104,72. From the histogram and frequency polygon, it can be inferred that student's Language Attitude of State Vocational High Schools 1 and 3 Serang Banten has a normal distribution.

Histogram of variable polygon of Language Attitude as follows:

Language Attitudes (X2)

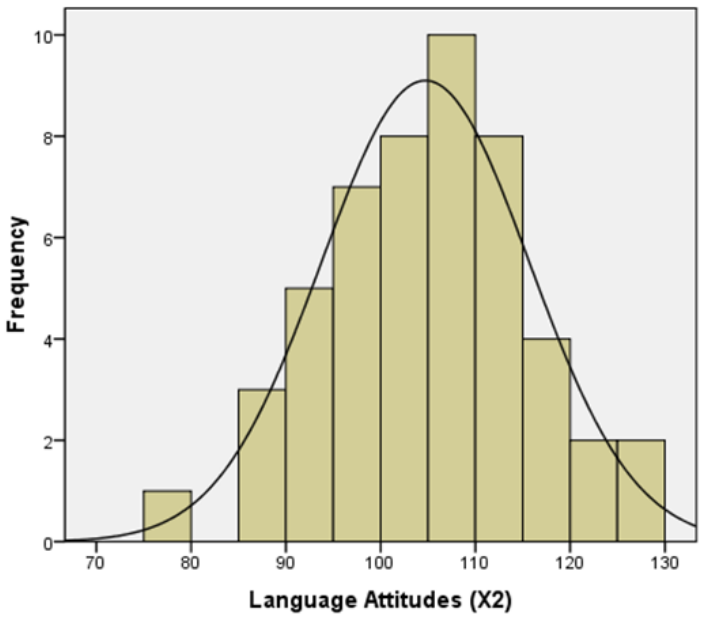

$\begin{aligned} \text { Mean } & =104.72 \\ \text { Std. Dev. } & =10.96 \\ N & =50\end{aligned}$ 


\section{DISCUSSION}

The effects of student Perception on Teacher's Pedagogic Competence (X1) and Language Attitude (X2) towards Student's English Achievement (Y).

The research result above concludes that student Perception on Teacher's Pedagogic Competence and Language Attitude have given the positive effects to the advancement of Student's English Achievement at State Vocational High Schools 1 and 3 Serang-Banten. It means that student Perception on Teacher's Pedagogic Competence and Language Attitude have contributed the significant effects to the improvement of Student's English Achievement at State Vocational High Schools 1 and 3 Serang-Banten.

The effects of student Perception on Teacher's Pedagogic Competence (X1) towards Student's English Achievement (Y).

The research result above concludes that student Perception on Teacher's Pedagogic Competence has given the positive effects to the advancement of Student's English Achievement at State Vocational High Schools 1 and 3 Serang-Banten. It means that student Perception on Teacher's Pedagogic Competence has given the significant effects to the improvement of Student's English Achievement at State Vocational High Schools 1 and 3 Serang-Banten.

The effects of Language Attitude (X2) towards Student's English Achievement (Y).

From the research result and the available theory. It can be concluded taht Language Attitude has given the positive effect to the advancement at State Vocational High Schools 1 and 3 SerangBanten. It means that the high Language Attitude has contributed the significant effect to improvement at State Vocational High Schools 1 and 3 Serang-Banten.

\section{CONCLUSION}

The study aimed to know the effect of Student Perception on Teacher's Pedagogic Competence and Language Attitude towards Student's English Achievement of the Second grade students at State Vocational High Schools 1 and 3 in Serang-Banten, it is concluded as follows:

The first one, there are any significant effects of Student Perception on Teacher's Pedagogic Competence and Language Attitude jointly towards Student's English Achievement of the Second grade students at State Vocational High Schools in Serang-Banten. This is proved by Sig $=0.000<0.05$ and Fo $=47,843$. The Student Perception on Teacher's Pedagogic Competence and Language Attitude together accounted for $67,1 \%$ of the variation in Student's English Achievement.

The second one, there is a significant effect of Student Perception on Teacher's Pedagogic Competence towards Student's English Achievement of the Second grade students at State Vocational High Schools in Serang-Banten. This is proved by Sig=0.010 $<0.05$ and th $=2,677$. Variable of Student Perception on Teacher's Pedagogic Competence contributes 34,2\% in enhancing Student's English Achievement.

The last one, there is a significant effect of the Language Attitude towards student's English Achievement of the second grade students at State Vocational High Schools 1 and 3 Serang. This is proved by Sig $=0.000<0.05$ and th $=4,137$. Variable of Language Attitude contributes $21,95 \%$ in enhancing Student's English Achievement.

By knowing the calculation of data analysis, the implications of variables : Student Perception on Teacher's pedagogic Competence (X1) and Language Attitude (X2) towards Student's English Achievement (Y). Are as folows :

1). Student perception on teacher's pedagogic competence gives positive information that teacher's competence also pedagogic can assist the student's to learn English as a subject in general, and particular to improve student's English achievement. It can be underlined that the result gives the significant effects towards student's English achievement. 
2). Language Attitude based on the result of the research data analysis gives thepositive effect significantly towards student's English achievement. It can be implied that this variable improves student's English achievement.

\section{REFERENCES}

Alisuf Sabri. (1995). Pengantar Psikologi umum dan Perkembangan. Jakarta: Pedoman Ilmu.

A. Fauzi. (1999). Psikologi Umum. Bandung: CV.Pustaka SetiA.

Ajzan, I. (1988). Attitudes, personality and behaviour. Chicago: Dorsey Press.

Abdullah, S. Ibrahim. (2013). Aplikasi Komputer dalam Penyusunan Karya Ilmiah. Tangerang. Pustaka Mandiri.

Baker, C. (1992). Attitudes and language. Clevedon: Multilingual Matters.

Bernat, E. and Gvozdenko, I. (2005). Beliefs about language learning: Current knowledge, pedagogical implications, and new research directions. TESL EJ 9 (1): 1-21

Djaali (2008). Psikologi pendidikan. Jakarta: PT. Bumi Aksara

Gardner, R. (1980). On the validity of affective variables in second language acquisition: Conceptual and statistical considerations.

Gardner, R. (1985). Social psychology and second language learning: The role of attitude and motivation. London: Edward Arnold.

Irwanto. (1996). Psikologi Umum, Jakarta: PT. Gramedia Pustaka Umum. Cet Ke-4

John M.Echol and Hasan Sadely. (1997). Kamus Bahasa Inggris Indonesia. Jakarta: PT Gramedia Pustaka Utama.

Purwanto, Profesionalisme Guru, Teknodik, No. 10/VI/Oktober/2002.

Slameto, (2003). Belajar dan Faktor-faktor yang Mempengaruhinya. Jakarta: PT.Rineka Cipta.

Slameto, W.Sarwono. (2010). Belajar dan faktor-faktor yang mempengaruhinya. Jakarta: Rineka Cipta.

Syah, Muhibin. (2011). Psikologi Pendidikan. Bandung: PT. Remaja Rosdakarya

Tatan Zaenal Mutakin. (2015). Suplemen Aplikasi Komputer Dalam karya Penyusunan Karya Ilmiah. Pustaka Mandiri.

Wasti Soemento. (1998) Psikologi Pendidikan; Landasan Kerja Pemimpin Pendidikan. Jakarta: PT. Rineka Cipta.

Wenden, A. (1991). Learner Strategies for Learner Autonomy. London: Prentice Hall.

Unindra. (2017). Buku Panduan Penulisan Tesis. Program Pasca sarjana Universitas Indraprasta PGRI. Jakarta. 